\title{
Ecology through the eyes of a non-ecologist ${ }^{\star}$
}

\author{
Ekologia oczami nieekologa
}

\author{
Janusz Uchmański \\ Institute of Ecology and Bioethics, Cardinal Stefan Wyszyński University in Warsaw, Poland \\ ORCID: https://orcid.org/0000-0001-8087-8371•j.uchmanski@uksw.edu.pl
}

\begin{abstract}
Ecology is a branch of biology that deals with the life of plants and animals in their environment. Nature protection are practical actions where ecology is applied. Ecology is the most biological branch of biology because it deals with individuals in their living environment, and individuals "exist" only in biology. The most important issue being considered in ecology is biodiversity: its changes and its persistence. In their research, ecologists focus on the functioning of ecological systems. In classical terms, they assume that the most important mechanism is density dependence. Mathematical models traditionally applied in ecology include ordinary difference and differential equations, which fits well with the assumption of density dependence, but this results in ecology being dominated by considerations of the stability of ecological systems. Evolutionary biology and ecology have separate areas of interest. Evolutionary biology explains the formation of optimal characteristics of individuals. Ecology also takes into account those individuals who have lost in the process of natural selection. The mathematical methods used in classical ecology were developed for the use of physics. The question arises whether they give a precise picture of the dynamics of ecological systems. Recently, a view has emerged stating that in order to see the importance of full-scale biodiversity, we should refer to individuals (rather than population density) as basic "atoms" that make up ecological systems. In ecology, we call this an individual-based approach. However, it gives a very complex picture of how ecological systems work. In ecology, however, there is an alternative way to describe the dynamics of ecological systems, i.e. through the circulation of matter in them and the flow of energy through them. It allows the use of traditional difference and differential equations in the formulation of mathematical models, which has proven itself in practical applications many times.
\end{abstract}

Keywords: ecology, biodiversity, mathematical models, Volterra models, individual-based approach

Streszczenie: Ekologia jest dziedziną biologii zajmującą się życiem roślin i zwierząt w ich środowisku. Ochrona przyrody to praktyczne działania, gdzie stosuje się ekologię. Ekologia jest najbardziej biologiczną dziedziną biologii, ponieważ zajmuje się osobnikami w ich środowisku życia, a osobniki „istnieją" tylko w biologii. Najważniejszym problemem, jaki rozważa się w ekologii jest różnorodność biologiczna: jej zmiany oraz jej trwanie. W swoich badaniach ekolodzy skupiają się na funkcjonowaniu układów ekologicznych. W klasycznym ujęciu zakładają, że najważniejszymi mechanizmami są zależności od zagęszzzenia. Model matematyczne stosowane tradycyjnie w ekologii to zwykle równania różniczkowe i różnicowe, co dobrze pasuje do założenia o zależnościach od zagęszczenia, ale powoduje to, że ekologia została zdominowana przez rozważania nad stabilnością układów ekologicznych. Biologia ewolucyjna i ekologia mają rozłączne dziedziny zainteresowania. Biologia ewolucyjna wyjaśnia powstawanie optymalnych cech osobników. Ekologia bierze pod uwagę także te osobniki, które przegrały w procesie doboru naturalnego. Metody matematyczne używane w klasycznej ekologii powstały na użytek fizyki. Rodzi się pytanie, czy dają one prawidłowy obraz dynamiki układów ekologicznych. Ostatnio pojawił się pogląd, że, aby dostrzec znaczenie różnorodności biologicznej w pełnej skali, powinniśmy odwołać się do osobników (a nie do zagęszczenia populacji) jako podstawowych „atomów", z których składają się układy ekologiczne. Zwiemy to podejściem osobniczym w ekologii. Daje ono jednak bardzo skomplikowany obraz funkcjonowania układów ekologicznych. Wekologii istnieje jednak alternatywny sposób opisu dynamiki układów ekologicznych poprzez krążenie materii w nich i przepływ energii przez nie. Pozwala on przy budowie modeli matematycznych na stosowanie tradycyjnych równań różniczkowych i różnicowych, co wielokrotnie sprawdzało się w praktycznych zastosowaniach.

Słowa kluczowe: ekologia, różnorodność biologiczna, modele matematyczne, modele voletrrowskie, podejście osobnicze

\footnotetext{
"This article was originally published in Polish as Uchmański, Janusz. 2017. "Ekologia oczami nieekologa." Studia Ecologiae et Bioethicae 15(2): 27-39. The translation of the article into English was financed by the Ministry of Science and Higher Education of the Republic of Poland as part of the activities promoting science - Decision No. 676/P-DUN/2019 of 2 April 2019. Translation made by GROY Translations.
} 


\section{Introduction}

When I studied at the Faculty of Physics of the University of Warsaw in the 1970s, there was still an atmosphere of great breakthroughs in physics theories, which took place in the first half of the 20th century. We were taught by professors who belonged to the first generation of physicists born after the formulation of quantum and relativistic mechanics. Apart from our admiration for these achievements, there were also problems we encountered at the university, such as deep understanding of the processes occurring in our conceptions concerning the physical world, the role of theory and experiment, also understanding the importance of mathematical methods.

After graduation, I spent my entire professional life dealing with ecology and working with ecologists. My enemies said about me that I was not an ecologist. Indeed, I never learnt to recognize and name plants and animals, but my contact with physics, although lasting only a few years, allowed me to take a look at ecology in a completely different way and see what a traditionally educated biologist usually does not see. I would like to share some observations on this subject with readers in this article.

\section{Classification}

Ecology is a branch of biology, treated as a natural science, which deals with the life of plants and animals in their environment. The human being is not an essential element occurring together with other animals and plants in the environment. Their presence and its consequences are usually treated as disturbance of natural conditions in the environment.

Nature protection means practical actions whose objectives are contained in the name itself, where not only ecology is applied, but also the achievements of other sciences: technology, law and others. Nature protection is also a subject of humanist reflection. There is the same relationship between ecology and environmental and nature protection as there is between physics and technology: technology is the application of physics, whereas nature protection is the application of ecology, although in the latter case the expression "among other things" should be added because in nature protection, as I have already mentioned, other sciences - very different and not always natural ones - are used as well.

\section{Biologicality of ecology}

At this point, I will formulate quite a controversial view concerning branches of biology other than ecology and evolutionary biology, but it will help to understand the distinctiveness of the latter. I think that molecular biology is actually chemistry or maybe physics too. It deals with the description of the functioning of the organism on the level of atoms and chemical particles. Physiology, in turn, is also physics and chemistry of the organism, but now a physiologist is trying to understand the functioning of the organism using the knowledge of other than in the case of molecular biology branches of physics: classical mechanics, hydrodynamics and electrodynamics. Obviously, the blood flow through a blood vessel is a slightly different and more complicated issue than simple hydraulics, which is the flow of water in a pipe, but in both cases, the methods applied to the mathematical description of these processes will be very similar. Thus, while recognising that in the case of molecular biology and physiology, physics and chemistry are applied to a very specific system, such as an animal or plant organism, I will continue to argue that their degree of biologicality is low compared to ecology.

In my opinion, ecology is the most biological branch of biology. It is so because it deals with individuals in their living environment, and individuals only "exist" in biology. In physics, we have elementary particles, photons, material point, stars and galaxies, in chemistry we have elements, atoms and chemical molecules. Biological individuals are created by division or budding, they hatch from an egg or they are 
born. Later they grow and develop, then they reproduce and finally die. Physics and chemistry deal with objects that cannot do that. An electron, which was created just after the Big Bang, has a great chance that it will last forever in unchanged form. The most important feature of biological individuals, i.e. a property that distinguishes them from objects dealt with by other natural sciences, is that they are able to make copies of themselves, that is, to reproduce, and they do so in very different ways. To sum up, as life exists in the form of individuals and ecology deals with them as well as relationships between them in the context of the environment in which they live, it is pure biology.

The second equally biological branch of biology is evolutionary biology. In a sense, this is also because it also deals with individuals, more precisely, the formation of their features which are a result of natural selection. This notion is not used by any other natural science. Natural selection can only be found in biology, as it appears only in the situations when the objects we deal with can create more or less exact copies of themselves. As we already know, only biological individuals have this ability. This - although in a different way than in ecology - makes evolutionary biology also a very biological branch of biology.

\section{Major ecological problem}

Ecology deals with the issue of biological diversity. It has several dimensions. Individuals can be classified into species - if they reproduce sexually - or clones - if there is asexual reproduction (in the case of asexual organisms we also use the term species to which we include different clones based on the similarity of certain significant features). The number of species on Earth is not known, but there are probably tens of millions of them. We talk then about the diversity of species. Individuals also vary within species. This is the second - individual-based - dimension of biodiversity. These differences are not only the result of differences in sex or age, but individuals of the same species, the same sex and at the same age will also differ, for example, because there are different types of interaction between them. Finally, the features of the individuals change with their age.

The population size is also significant if we take a look at biodiversity. The population dynamics - its changes over time - is also justified to be included in several issues related to biodiversity. The population size of different species may be highly different (Andrewartha and Birch 1954; Harper 1977). Some species are represented by huge population size, others by a very small one. The species may exist in the form of multiple local populations with a very local range of impact of their individuals on the environment and other local populations or may form a single global population. The population size very rarely remains unchanged. Most frequently, they change over time. They can change chaotically, but they can also grow systematically, oscillate regularly or be characterized by dynamics typical of an outbreak, i.e. when a population remains at a low level for a longer period and then rapidly increases reaching very high values, and such behaviour appears at regular intervals, causing periodic dominance of one species (Barbosa and Schultz 1987).

As speciation, i.e. the formation of new species, takes place mainly through geographical isolation (Mayr 1964; Coyne and Orr 2004), the number of species should be in some way proportional to the number of habitats available on Earth. Nevertheless, it is slightly more than 500 million years that we have seen a rapid increase in species diversity. Ecologists are wondering why life on Earth is so highly varied (Rosenzweig 1995). What are the reasons that the Earth does not look like the planet Solaris from Stanisław Lem's novel, which, as we remember, was inhabited by a single species, represented by one individual, but covering this whole strange planet like an ocean? What causes an increase or decrease in biodiversity? However, the most important question is different. What are the reasons for the fact that biodiversity 
persists, and after every event reducing it, life on Earth returns in even greater abundance and diversity? After all, we see many reasons to believe that biodiversity should rather decline: great extinctions and global catastrophes that have occurred in the geological history of the Earth, current extinction of species and now observed invasions of alien species into areas inhabited by local species, competition between species, presence of predators and parasites, limited environmental resources, as well as the human activity.

\section{Ecological "mechanics"}

Ecologists are trying to solve these and many other mysteries concerning the functioning of the living world on Earth. In doing so, they usually have to consider a given ecological system (Golley 1993), because it is easy to see, also from our daily human experience, that the life of each individual is passed in interactions with other individuals of the same species, but also with individuals of other species from its surroundings, and with the environment. Such ecological systems are, for instance, forest or lake, but also arable land. These are usually open ecological systems. They often have difficult to draw boundaries. However, the use of the concept of 'ecological system, apart from being a necessity (as it has good objective justification), also makes ecologists' work much easier.

As we mentioned earlier, what distinguishes biology from other natural sciences is the fact that it deals with individuals. None of them, regardless of which species it belongs to, resembles objects dealt with by physics or chemistry. Thus, a natural way of dealing with the above-mentioned issues would be starting with individuals and their groupings called populations. Ecologists know a lot about individuals, their functioning as a whole (about their growth and development, reproduction, energetics) in various ecological situations, but when answering the above-mentioned questions, they use completely different approaches. It is a lot of mathematicians' fault, who persuaded them to do it this way.
Ecologists use the so-called "density-dependent" approach. The population density is called the number of individuals of a specific species per space unit (area or volume). Since the 1920s, i.e. almost a hundred years ago, there has been a paradigm in ecology that the dynamics of ecological systems (changes in densities of individuals representing species making up the ecological system) depend on the densities themselves. There are usually many negative statistical correlations between population density and numerous variables that characterize the population. For instance, in even-aged populations (comprising individuals of the same age), the average weight of an individual usually decreases with an increase in population density. The same is true for the average number of litter per individual in the population. When it comes to thinking about the functioning of ecological systems, such dependencies have also been used for a long time in ecology. The only problem is that by concentrating on average values of individuals' features in a given population, we lose what, as we have established earlier, is the most important feature of the living world, namely, its diversity. After all, these averages are calculated for some sort of distribution of characteristics, and these distributions may consist of individuals with very different features, reacting very differently to what is happening in the population. The density as a measure of the state of a population is a great simplification as well because we know how many individuals per unit of space are, but we do not know what these individuals are. In a certain sense, density is also an averaging measure because it treats all individuals per unit of space in the same way, having no interest in differences between them. Finally, population density is a measure of very limited use. It ceases informing about the status of a population when spatial effects become significant. For instance, in the case of sedentary organisms and distributed unevenly in an area. We deal with such a situation in natural terrestrial plant communities. 
In the past, several decades ago, attempts were made to formulate assumptions about the functioning of ecological systems using the then-popular systems theory and cybernetics (Trojan 1980). The ecological systems were presented as self-sustaining ones that maintain their stability thanks to a negative-feedback network. The latter was attributed to dependencies on densities of various variables and parameters that characterize ecological systems. The term homeostasis, taken from physiology, was even used with reference to ecological systems. This approach did not withstand confrontation with evolutionary biology. The existence of such effective feedback to ensure the stability of the system would require to sacrifice the reproductive interests of an individual for the benefit of the ecological system. Typically, the system's persistence is at risk as a result of its demographics. Too large or too small populations of the species forming it are a threat to the disintegration of such a system. To preserve the arguments of those who support the application of the systems theory in ecology, it would have to be assumed that individuals can limit their current reproductive success in favour of the future stability of the ecological system. Unfortunately, evolutionary biology teaches us that group selection, i.e. a mechanism that encourages the occurrence of characteristics in an individual that are good for a group of individuals but they are unfavourable for this individual, works in nature to a very limited extent and under very specific conditions. Thus, after this trip towards the systems theory, ecologists have remained aware of the basic problem they are facing, and which they have become aware of when looking at the achievements of their colleagues in the field of evolutionary biology: how to reconcile the fact that an individual is focused on maximizing short-term reproductive success (as evolutionary biology convinces us) with the long-term persistence of the ecological system.

In ecology, attempts have been made to formulate various types of laws and prin- ciples. For example, Gause's competitive exclusion principle (Gause 1934) says that only $n$ species can permanently co-exist competing for $n$ resources. There is also a principle formulated by Robert May (May 1973), which says that the complexity of the ecological system entails its stability. None of these has stood the test of time. None of them has reached the status of laws and principles, known from physics. Each of them can be said that they are both true and false, indicating numerous examples - derived from nature observation, experiments and mathematical models - for and against them.

Hence, despite a very large number of results of experiments and observations of ecological systems and their components, as well as attempts to formulate mathematical models, which have provided a great deal of detailed ecological information, ecology, as a whole, remains a science with a rather "fuzzy" status. To justify this state of affairs, we can only say that ecology deals with really complex systems, whose basic component - an individual - is already much more complicated than what physicists or chemists deal with.

\section{Mathematicity of ecology}

Ecology has a mathematical aspect, as it uses mathematical models (Uchmański 2015). If we take a look at whole biology, we can see that this process began, at the earliest, in ecology (Kingsland 1995). In the twenties of the last century, the standard of applied mathematical methods was established in ecology. This is mainly due to an Italian mathematician - Vito Volterra (Volterrra 1931), an American chemist - Alfred Lotka, an American zoologist Raymond Pearl and an American ecologist - Robert MacArthur. These models traditionally take their name from the former surname, thus they are called Volterra models. The experimental basis of this approach is, however, due to the aforementioned Russian ecologist, Georgii Gause.

The world of inanimate nature - physics - has always been a source of inspiration for mathematicians and mathematics. 
Mathematics has developed largely thanks to mathematical models and methods needed to describe physical phenomena and processes. Ecology was different. Nothing new in mathematics was invented for ecology. However, methods long applied in physics - differential and difference equations (May 1976; May and McLean 2007) - were adopted in ecology. Let us list the most common of these models: exponential growth equation describing unlimited population growth; logistic equation for the description of limited population growth, as well as a system of two or more differential and difference equations used for describing changes in the population density of competing species, predators and their preys, parasites and hosts, or populations of species whose interactions are characterized by mutualism. The latter models, which describe multi-species systems, are previously mentioned models of the Volterra type.

The use of differential and difference equations fits very well into the paradigms of dependence on the density adopted in ecology. This is because it is assumed that a state variable correctly and fully describing the state of a population is its density. In turn, the Volterra type model (i.e. an appropriate differential or difference equations or their system) gives us a formula for the rate of change in this density. On the right side of these equations, there is also density (or densities in the case of a system of equations) and several parameters that are related to the average rates of progeny production and mortality of individuals in the population. Thus, by solving such an equation or their system, we get population densities in successive time steps or population densities as functions of time.

The use of just such mathematical methods is great facilitation in testing the features of solutions of these models. This is because we have an entire arsenal of methods for analysing this type of equations at our disposal (Maynard Smith 1974; Bazykin 1985). From the more known ones and providing very illustrative information about the dynamics of a described system, a qualitative analysis of systems of differential equations can be mentioned as an example. On the other hand, these methods were not developed for ecological purposes. They are applied in physics; from there they were taken and originally were used to describe e.g. movements of material points. It is rather an ecology that was pressed into the framework of the already formulated mathematical schemes. The question is - was it a proper approach? Is this a proper picture of the dynamics of ecological systems, which is provided by the Volterra models?

\section{Stability of ecological systems}

Ecologists have had a huge number of nature observations. In ecology, an equally large number of experiments were conducted in laboratories and in natural conditions. Hence, we have a great deal of information about ecological systems - about their dynamics, functioning, as well as a variety of relationships and dependencies. However, the generalizations about the nature and features of ecological systems do not come from this large number of facts. As it is usually the case of natural sciences, they emerge as the result of studying mathematical structures that describe nature.

In this respect, ecology has few possibilities. If mathematical structures that describe the features of ecological systems are differential or difference equations, it is a natural reaction to study conditions for the stability of solutions of these equations. That is what happened in ecology. In their search for answers to the basic ecological question about the persistence of biodiversity, ecologists have started to look for such assumptions, mainly about values for the parameters as well as the structure of systems of differential equations describing multi-species ecological systems (although the general scheme of the model building has always been the Volterra one), that provide stable solutions. In this case, the term stability means the permanent co-occurrence of all species forming an ecological system - in a stable system, the population densities (making up an 
ecological system) may change, but they should not reach zero or grow unlimitedly.

It must be admitted that many such conditions of stability have been formulated in ecology (Swirezew and Logofet 1978). Some of them were confirmed by observations and experiments, while others not. As they were formulated based on relatively simple, usually linear differential and difference equations, even minor modifications of these equations gave results that were significantly different from the original ones. For example, the competitive exclusion principle, known from simple laboratory experiments, formulated by Gause in the twenties of the last century, is confirmed in the simplest models of the Volterra type. However, relatively minor modifications of this model show that it is possible to build a model whose results can be interpreted in an opposite way to the Gause's principle: any number of competing species can coexist permanently, competing for only one type of resource. In turn, the observations of ecological systems in nature do not give an unambiguous answer to the question, what makes them permanent.

In ecology, there is no close linkage between the part of the ecology that deals with theoretical considerations supported by mathematical models and the other part focused on observations and experiments, as in the case of physics, where both theoretical and experimental physics exist. In ecology, a major part of statements is formulated verbally in natural language. This often leads to the overuse of concepts or their use without their clear definition. Such a status gained the term stability in ecology. It is used with many meanings. It usually plays the role of a skeleton-key, but its true power of explanation is very suspicious.

\section{Ecology vs. evolutionary biology}

Evolutionary biology deals with adaptations. Adaptations are features of individuals that ensure their reproductive success and thus they have a chance to become established in the population (Ridley 1993; Stearns and Hoekstra 2005). Hence, evo- lutionary biology searches for the optimal form of an individual. Ecology, in turn, deals with the real life of individuals. In ecology's area of interest, there are obviously individuals with optimal features and they successfully passed on their optimal characteristics to their litter, but there are also such individuals which, despite having optimal characteristics, were unlucky and did not gain reproductive success for different reasons, as well as those that do not have such optimal features because they carry unfavourable gene variations or were not given such optimal features to develop. Incidentally, the individuals of the last two categories are usually much more numerous in each generation than those that belong to the first category. Therefore, to put it briefly, one can say that evolutionary biology deals only with successful products of natural selection, whereas ecology also deals with "waste" of this process.

The process of natural selection is an optimization process in which an optimal dimension and form of a goal are achieved provided that some restrictions are met. Adaptations that are the product of this process - as we see them now - maximise the short-term reproductive success of an individual. As it was explained earlier, there are no adaptations that are made primarily to ensure the balance, stability or persistence of a population or an entire ecological system. This is because, as it is currently believed, the group selection, which could encourage the emergence of such beneficial characteristics for a group, works to a very limited extent only. Certainly, adaptation may have such a beneficial effect on the group, but it will only be a natural by-product of its action, unintended by natural selection. One should rather expect something the opposite. Adaptations that ensure the reproductive success for an individual in the short run rather act against equilibrium, stability and persistence of a population and ecological system. As I mentioned earlier, we are now dealing with a fundamental question in ecology, arising between ecology and evolutionary biology: if not natural 
selection, what ensures the persistence of biodiversity?

\section{Individual-based approach}

The view, very popular in ecology until now, that factors depending on density determine the functioning of ecological systems, which is supported additionally by a traditional way of mathematical modelling of the dynamics of these systems, has overshadowed several aspects of biodiversity, which we have discussed earlier. In the last two decades, however, another view emerged, saying that in order to recognize the importance of full-scale biodiversity, we should go back to the roots and refer again to individuals (not to population density) as basic "atoms" the ecological systems are composed of. In ecology, we call this an individual-based approach (Grimm and Railsback 2005).

How can this approach be applied to mathematical modelling of the dynamics of ecological systems? The general idea is very simple. We do not attempt - as is the case with the classic approach - to formulate an equation that describes such dynamics immediately, but rather we wonder how individuals being a part of a given population behave. How do they use environmental resources? What are the interactions between them? How do they interact with one another? Which one reproduces and which one dies without progeny? The dynamics of population sizes that are part of an ecological system is, in a sense, in passing. It is a by-product of the above-mentioned events and processes. Just from time to time, we can ask the model to count how many individuals there are in a population. Population density no longer plays a central role in the model. It is not the state variable which everything that affects the dynamics of the system depends on. Dependencies on density occur in individual-based models in a form that is appropriate to their importance. For instance, when describing interactions among individuals, it is reasonable to assume that the results of these interactions depend on the number, but also the quality, of the individuals interacting with one another.

The set of needs that emerge when we take the individual-based approach is in fact small (Uchmański and Grimm 1996). To build an assumption concerning the basic processes and phenomena affecting individuals in populations, we basically need information about the birth and death of an individual, its growth and development, about progeny production, and finally most importantly - about interactions with other individuals of the same and other species.

If we take a look at the arsenal of methods proposed by mathematicians, it will turn out that many of them perfectly fit to our needs when we begin to apply the individual-based approach. Some of them even provide mechanistic descriptions of phenomena and processes that are very useful in the individual-based approach to modelling the dynamics of ecological systems. This applies, e.g., to descriptions of interactions among individuals. We have many models describing energetics of an organism, its development and growth. This applies both to animals and plants. In the case of the latter, it is more difficult, as the development of an organism also involves the formation of a complex and very flexible, spatial plant structure.

There is also a great deal of experimental data that are useful in the individual-based approach. The so-called ecological bioenergetics is particularly well-deserved in this respect. However, most of the ecology-related experiments were conducted by ecologists who were followers of the density-dependent paradigm. This means that these experiments provide information concerning mean values of the measured variables and parameters, and basically their usefulness is reduced to the fact that they can be used to check predictions resulting from the individual-based approach. This is because - without considering the dependence on density as a driving force for the dynamics of ecological systems - it should also give, as a by-product, similar dependencies. 
The fact that in the individual-based approach we consider an individual to be an essential component of ecological systems means that we must recognize the importance and consequences of the fact that individuals vary. The individual variability, which is the result of separate individuality of each individual in the population, is, in my opinion, the most important consequence of applying the individual-based approach in ecology. We must consider the individual variability as an assumption in individual-based models, but these models are also obliged to create such variability, and we must take it into account when interpreting model results. Much more experimental research should be related to individual variability because, until now, it has been noticed almost exclusively by plant ecologists. For this reason, the Volterra models, which neglected this variability, were not applied in plant ecology. Taking the population density as a state variable and consequently neglecting the individual variability is perhaps the greatest sin of classic, Volterra models in ecology. It causes a situation when two models for the same process - classic and individual one - will probably give different results. Let us imagine the following example. A population covers an area of $s$. Then population density will be equal to population size divided by $s$. Let us assume that in a certain generation the population size decreases to one individual. Then the population density will be equal to $1 / s$. In the Volterra model, let us say in the form of a differential equation, where the state variable - density - is a real number and where solutions are continuous and asymptotic, the density may have even smaller values and the process of reaching zero can take a long time. It is different in the individual-based model. If the population size decreases to 1 , it all depends on what the only one individual is like. If it can produce at least one offspring under current conditions of the environment, then the population continues, if not - the population dies out immediately.

What image of nature gives an individual-based approach to ecology? Here, a comparison with mathematical objects called fractals comes to my mind. These are very complex and irregular geometric structures when we look at them as a whole. It is difficult for us to understand the rules by which they have been created. However, fractals can be created in a very simple, even boring, way. A fractal is a complex geometric structure because it is created by repeated adding a small element (module) of simple geometry to an already existing structure. The same applies to ecology. We have modules - individuals, we know their features and interactions between them. These modules are used to make a population. An emerging image is complex because there are many modules. It is difficult for us to understand how nature works when we look at it as a whole. However, we can do the same as in the construction of fractals, where different modules repeatedly iterated give different structures at the end of this process. Employing individuals, we can build typical models for typical ecological situations. They must be subject to experimental verification, obviously, but let us leave it to the ecologists-experimenters' ingenuity.

We cannot naively expect that a single equation - let us say, a logistical equation - will describe all single populations. We work with an object whose basic feature is diversity. For various species, different ecological groups, diverse ecological systems, we will have different schemes of model building. From them, you will be able to make a description of a larger whole and understand its functioning. There is a need to look for typical patterns in nature, which will be used to verify such constructed models (Grimm et al. 1996).

Physicists and natural philosophers speak most frequently about the mathematicity of nature (Heller and Życiński 2010; Lemańska 2013; Heller 2014). This leads some of them to very far-reaching consequences as to the true nature of reality (Tegmark 2015). This term means that nature can be explored by analysing the characteristics of mathematical structures used to describe it. It is a very attractive way of 
looking at nature, but I think it is only right in the case of physics and inanimate nature. When talking about living nature, we should rather use the term algorithmicity of nature (Uchmański 2016). In ecology, it is not possible to build such mathematical models as those in physics, i.e. models analysed with analytic methods. Such an attempt - in my opinion, unsuccessful - were the Volterra models which used mathematical methods borrowed from physics. The fact that life exists in the form of individuals forces us to use an algorithmic description. The life history of an individual, their pursued goals and performed life functions can only be described in the form of an algorithm. Unfortunately, this has serious consequences. It means that in ecology we will have to use less elegant methods of computer simulations. On the other hand, this may not be the greatest difficulty to overcome when we get down to describing an animate nature. Perhaps this will require us, who are accustomed to the elegance of analytical methods used in physics, only to change our attitude to computer simulations, which, after all, are increasingly applied in natural sciences.

\section{Conclusions}

A huge amount of information obtained from observations and experiments has been collected in ecology. Such information was almost always collected according to a certain image of the natural world, which an experimenter considered to be right, or served to confirm or refute a certain ecological hypothesis. As classic ecology was dominated by a view which in every corner of nature saw density dependencies, experiments and observations are mostly burdened with this view. Although there are experiments and observations conducted in the spirit of the individual-based approach or those that can be interpreted in this spirit, there are far fewer of them. If we consider the individual-based approach to be appropriate for ecology, we should call for more experimentation to develop the individual-based approach in ecology. We need experiments to be able to understand, above all, how individuals achieve their life goals - growth, development, reproduction - in interactions with other individuals of the same and other species, as well as in relation to the physical environment. Many years ago, bioenergetics was a field of ecology, almost by definition, predestined for this type of research. Unfortunately, when it was developing intensively, bioenergetics limited its interest to an individual isolated from the influence of other individuals. Later, it was dominated by researchers interested in evolutionary biology and has never passed through the stage of studying the bioenergetic aspects of interactions between individuals.

The picture of the ecological system and its dynamics, which emerges from the individual-based approach, is undoubtedly complex. It is a little simpler in the case with sedentary organisms- e.g. terrestrial plants, as in this case, we have quite good ideas about how to describe the interactions between such organisms. This picture is very complicated for most animals moving with respect to the environment. Firstly, we know little about the mechanisms of interactions between these types of organisms, and their variety is likely to be enormous. Secondly, the presence of usually very large numbers of interacting individuals in a population leads to a very specific type of randomness. Even when the life history of an individual is completely deterministic (usually it is not so), the fact that a population usually consists of very many such individuals gives each of them a subjective sense of randomness, because it is not able to predict all"movements" of other individuals in the population (Heller 2012). In addition to the search for typical functioning patterns of ecological systems, which I have already mentioned before, the study of individual variability, different dimensions of randomness and the relationship between the two phenomena in ecological systems and their significance for the dynamics of these systems also seem important elements of ecological research.

The world of animate nature is indeed very complex and diverse. Even now, how- 
ever, when we do not fully understand its diversity from the perspective of individual-based approach, we can use a description, the correctness of which is proven by the fact that it works perfectly well in practical ecological applications. Ecological systems can be thought of as giant converters of energy and matter, and their dynamics can be described in terms of the flow of energy and the circulation of matter through them. This description is not as detailed as it is required by the individual-based approach. We are not interested in the fate of individuals. Most often we limit ourselves to the trophic level or the species that make up the trophic level as the basic elements from which we build our idea of the ecological system. We wonder how much energy or matter from the environment or a lower trophic level is absorbed in a unit of time by a particular trophic level and transferred it to higher levels. We have a whole arsenal of well-developed methods of environmental chemistry to measure these flows. Such an approach has proven its usefulness in testing for water eutrophication (we then deal with phosphorus and nitrogen circulations in ecological systems) or global warming when we are interested in carbon circulation in the biosphere. Mathematical models are also constructed in this field of ecology. However, to the delight of the proponents of classical mathematical ecology, the models using both differential and difference equations work well here. When studying chemical elements cycling and energy flows through ecological systems, we will not get an exhaustive answer to the most important question of ecology, concerning the reasons for the existence and persistence of biodiversity. However, we deal with the background against which this diversity has a chance to manifest itself, as well as we show that ecology, seen as a branch of biology, can be useful in solving very important problems of practical nature, concerning nature conservation.

Finally, I would like to share with readers some comments about ecology that are not part of science. I would like to write about the aesthetic beauty of dealing with ecology. Most people like nature. This is expressed in different ways, depending on what tradition we come from. We like to watch nature, look at it and admire it. For most of us, nature is beautiful. An ecologist is concerned with what is beautiful for most people! I am very happy to be aware of this fact. Besides, an ecologist deals with macroscopic objects, i.e. those that they can see using their own senses, sometimes only supported by a microscope. Most physicists are deprived of such a possibility. This is also a great advantage of ecology. We try to understand the world of living nature that surrounds us, which we encounter from the first flashes of consciousness after birth and which enchants us with its richness and beauty until our last days.

\section{Bibliography}

Andrewartha, Herbert G., and Louis C. Birch. 1954. The distribution and abundance of animals. Chicago: The University of Chicago Press.

Barbosa, Pedro, and Jack C. Schultz (eds). 1987. Insect outbreaks. San Diego: Academic Press. Coyne, Jerry A., and H. Allen Orr. 2004. Speciation. Sunderland: Sinauer.

Bazykin, Aleksandr D. 1985. Matematiceskaja biofozika wzaimodejstwujuscih populacji. Moskwa: Nauka.

Gause, Georgii F. 1934. The struggle for existence. Baltimore: Williams and Wilkins.

Golley, Frank B. 1993. A history of the ecosystem concept in ecology. More than the sum of the parts. New Haven: Yale University Press.

Grimm, Volker, Karin Frank, Florian Jeltsch, Roland Brandl, Janusz Uchmański, and Christian Wissel. 1996. "Pattern-oriented modelling in population biology." The Science of the Total Environment 183: 151-166.

Grimm, Volker, and Steven Railsback. 2005. Individual-based modeling and ecology. Princeton: Princeton University Press.

Harper, John L. 1977. Population biology of plants. London: Academic Press.

Heller, Michał. 2012. Filozofia przypadku. Kosmiczna fuga $z$ preludium i coda. Warszawa: Copernicus Center Press. 
Heller, Michał. 2014. Elementy mechaniki kwantowej dla filozofów. Warszawa: Copernicus Center Press.

Heller, Michał, i Józef Życiński. 2010. Matematyczność przyrody. Kraków: Petrus.

Kingsland, Sharon E. 1995. Modeling nature. Episodes in the history of population ecology. Chicago: The University of Chicago Press.

Lemańska, Anna. 2013. "Matematyczność czy matematyzowalność przyrody?” Studia Philosophiae Christianae 49: 5-24.

May, Robert M. 2013. Stability and complexity in model ecosystems. Princeton: Princeton University Press.

May, Robert M. (ed.) 1976. Theoretical ecology. Principles and applications. Philadelphia: W. B. Saunders Company.

May, Robert M., and Angela McLean (eds). 2007. Theoretical ecology. Principles and applications. Oxford: Oxford University Press.

Maynard Smith, John. 1974. Models in ecology. Cambridge: Cambridge University Press.

Mayr, Ernst. 1964. Systematics and the origin of species from the viewpoint of a zoologist. New York: Dover Publications.

Ridley, Mark. 1993. Evolution. Oxford: Blackwell Scientific Publication.
Rosenzweig, Michael L. 1995. Species diversity in space and time. Cambridge: Cambridge University Press.

Stearns, Stephen C., and Rolf F. Hoekstra. 2005. Evolution. An introduction, Oxford: Oxford University Press.

Swirezew, Jurii M., and Dmitrii O. Logofet. 1978. Ustojciwost biologiceskih soobscestw. Moskwa: Nauka.

Tegmark, Max. 2015. Nasz matematyczny Wszechświat. W poszukiwaniu prawdziwej natury rzeczywistości. Warszawa: Prószyński i S-ka.

Trojan, Przemysław. 1980. Homeostaza ekosystemów. Wrocław: Ossolineum.

Uchmański, Janusz. 2015. „Matematyczność biologii." Filozofia i Nauka 3: 345-352.

Uchmański, Janusz. 2016. "Algorytmiczność biologii." Studia Philosophiae Christianae 52(1): 99-120.

Uchmański, Janusz, and Volker Grimm. 1996. "Individual-based modelling in ecology: what makes the difference?" Trends in Ecology and Evolution 11: 437-441.

Volterra, Vito. 1931. Lecons sur la theorie mathematique de la lutte pour la vie. Paris: Gauthier-Villars. 